\title{
De Novo Renal Cell Carcinoma of Native Kidneys in Renal Transplant Recipients: A Single-center Experience
}

\author{
DEMETRIOS MORIS, KIRIAKI KAKAVIA, CHRYSOULA ARGYROU, NIKOLAOS GARBIS, \\ JOHN BOKOS, SPYRIDON VERNADAKIS, KONSTANTINOS DILES, \\ GEORGIOS SOTIRCHOS, JOHN BOLETIS and GEORGIOS ZAVOS
}

Transplantation Unit, Laikon General Hospital, Athens, Greece

\begin{abstract}
Background: The risk of renal cell carcinoma (RCC) development in renal transplant recipients is 15-100 times higher than in the general population. The majority of RCCs found in renal transplant recipients develop in the recipient's native kidneys, only 9\% of tumors develop in the allograft itself. The mechanisms of development of RCC in native kidneys and renal allografts are not completely understood. We present our experience in renal transplant recipients with RCC of native kidneys providing valuable and clinically applicable treatment and follow-up data. Patients and Methods: The records of 2,173 patients who underwent renal transplantation in our Department between March 1983 and December 2015 were retrospectively reviewed. Using these data, we analyzed the incidence and types of posttransplant RCCs, as well as their clinical courses, focusing on native malignancies. Results: We found 11 RCCs (0.5\%) during the observation period in native kidneys. The mean $( \pm S D)$ follow-up period was $50.54 \pm 32.80$ months. Four patients died during this period (36.4\%). Conclusion: Most RCCs in renal transplant recipients are low-stage, low-grade tumors with a favorable prognosis. Their diagnosis is usually incidental. RCC development in the native kidney of renal transplant recipients is an early event, frequently observed within 4 to 5 years after transplantation. The different natural history of these tumors is still undefined. Further research is needed to determine whether these differences are due to particular molecular pathways or to biases in relation to the mode of diagnosis.
\end{abstract}

Currently, renal transplantation (KTx) is the primary therapeutic option in patients with end-stage renal disease

Correspondence to: Demetrios Moris, MD, Ph.D., Transplantation Unit, Laikon General Hospital, Agiou Thoma 17 Street, Athens, Greece. E-mail: dimmoris@yahoo.com

Key Words: Renal cell carcinoma, renal transplantation, prognosis, native kidney.
(ESRD) due to its superiority in terms of cost, efficacy and quality of life compared to dialysis (1). In order to achieve long-term allograft function, the use of highly potent immunosuppressive agents is compulsory to impede acute and chronic allograft rejection (2). The concomitant price to be paid, however, is the markedly increased incidence of malignancy in the post-transplantation period (3-6). Even if the incidence of malignancy is difficult to accurately calculate, a proportion of $6 \%$ to $11 \%$ of de novo malignancies has been reported among transplant recipients in Western countries (4-8); but it may be higher as there is a steady increase in graft survival, reflecting a risk of approximately 100 times greater than a normal age-matched population $(5,6,8)$.

Native kidney and renal allograft are affected by both benign (9), and malignant or metastatic tumors more frequently than previously thought. The risk of renal cell carcinoma (RCC) development in renal transplant recipients is 15-100 times higher than in the general population (10-12) and the rate among all malignancies is less than 5\% $(11,13-$ 16). The majority of RCCs found in transplant recipients develop in the recipient's native kidneys, with only $9 \%$ of tumors developing in the allograft itself. Tumors transmitted by donors represent only $0.02 \%$ to $0.2 \%$ of cases $(17,18)$. Most de novo allograft RCCs are single tumors.

The mechanisms of development of RCC in native kidneys and renal allografts are not completely understood. Moreover, the different natural history of these tumors is still undefined. Several risk factors have been suggested, including duration and type of immunosuppression, native kidney disease, recipient/donor age, pre-transplant dialysis time and microscopic hematuria (13). Because of the current lack of prospective multicenter series with clearly defined treatment and follow-up protocols of RCC in renal transplant recipients, particularly concerning metastatic disease and allograft tumors, which challenge the delicate balance between oncological safety and renal function, a broad variety of therapeutic and surveillance strategies exists. 
We present our experience on renal transplant recipients with RCC in native kidneys of the largest Greek Transplant Program, providing valuable and clinically applicable follow-up data.

\section{Patients and Methods}

The records of 2,173 patients who underwent KTx at our Department between March 1983 and December 2015 were retrospectively reviewed. Of these patients, 1072 received their transplants from living first-, second-, or third-degree relatives, 1101 from deceased donors and seven were combined kidney and pancreatic transplantations. Recipients presenting RCC were evaluated regarding histological type of neoplasm, presence of cysts, age, gender, time from KTx to RCC diagnosis, time from RCC diagnosis to endpoint (death or end of follow-up), use of immunosuppressive regimens, graft functional status and rejectionreturn to dialysis episodes. This study was carried out by our Department with the contribution of the Departments of Pathology and Nephrology. Using these data, we retrospectively analyzed the incidence and types of post-transplant RCCs, as well as their clinical courses, focusing on native kidney malignancies.

All patients under care of our Department received meticulous preoperative evaluations according to currently valid urological and nephrological guidelines on KTx. Post-transplant check-ups were performed at Laikon General Hospital by nephrologists at least twice a year and included semiyearly sonography of the graft and native kidneys.

For the present study, clinical, histopathological and surveillance data were collected of renal transplant recipients who developed a de novo RCC of native kidney after KTx. Study endpoints were defined as patient death or last follow-up before 31st December 2015. No patient was lost during the follow-up period.

Descriptive values were recorded as the mean, median and standard deviation. Tumors were staged according to the currently valid TNM classification of the Union Internationale Contre le Cancer (19) and graded according to the Fuhrman system (20).

Immunosuppression protocol. Immunosuppression (IS) regimens, at the time of KTx, were available for all participants. We typically use induction treatment with basiliximab or daclizumab, in all patients who undergo KTx. Recipients of kidneys from expanded criteria donors or any case with a cold ischemia time significantly longer than the mean time of our center (more than $16 \mathrm{~h}$ ), or in the case of established delayed graft function, receive induction therapy with antithymocyte globulin (ATG). During treatment with ATG, calcineurin inhibitors are discontinued and are reinstituted 1-2 days before cessation of ATG. All patients receive treatment with corticosteroids at the time of KTx, administered as 500-1000 mg of methylprednisolone during surgery, followed by $20-40 \mathrm{mg} /$ day (depending on the immunological risk) orally, and a gradual steroid taper in the absence of rejection. Maintenance immunosuppression consists of a calcineurin inhibitor, cyclosporine or tacrolimus (TAC), with mycophenolate acid (MPA) formulations and methylprednisolone. Patients at high immunological risk are preferentially treated with TAC and an MPA formulation in full dose, while those with a history of cancer are treated with an inhibitor of the mammalian target of rapamycin (mTOR), aiming at a goal of 6-8 ng/ml if combined with MPA, and 4-6 ng/ml if combined with a calcineurin inhibitor (21-24).
Statistical analysis. Results were statistically analyzed using the Fisher and chi-square tests for categorical data and $t$-test for continuous data. All statistical analyses were performed with the Statistical Package for the Social Sciences, version 17.0 (SPSS Inc., Chicago, IL, USA).

\section{Results}

General analysis. In the group of 2,173 kidney transplanted patients, we found 11 RCCs during the observation period, resulting in a cancer detection rate of $0.5 \%$. No patient had a pre-transplant history of malignancy. One patient developed papillary thyroid cancer and another developed non-Hodgkin skin lymphoma during the follow-up period. No case of RCC in renal allografts was found in our series. Different nephropathies caused ESRD requiring replacement therapy: four cases of chronic glomerulonephritis, two of polycystic kidney disease, and one each of hypertension, diabetes, congenital renal dysplasia, obstructive nephropathy and unknown cause, respectively.

Among the 2,173 patients who received renal transplants at our center during the past 30 years, post-transplant RCC developed in 11 patients $(0.5 \%)$, including six men (54.5\%) and five women $(45.5 \%)$. Seven patients $(63.6 \%)$ received a graft from a deceased donor and four (36.4\%) from a living one. The mean $\pm \mathrm{SD}$ age at $\mathrm{KTx}$ was $44.82 \pm 13.51$ years (range $=18-62$ years) and the mean age at RCC diagnosis was $57.45 \pm 11.91$ years (range $=33-75$ years). The mean time from KTx to RCC diagnosis was $151.45 \pm 92.15$ months and the mean time from RCC diagnosis to an endpoint was $50.54 \pm 32.80$ months. Four patients died during the followup period, indicating a disease-specific mortality rate of $36.4 \%$. All patients who died did so with a functioning graft. The most common cause of death was metastatic diseasegeneralized carcinomatosis (4/4 cases, $100 \%)$. The mean serum creatinine concentration at cancer diagnosis was $1.68 \pm 0.9 \mathrm{mg} / \mathrm{dl}$ (median $=1.72 \mathrm{mg} / \mathrm{dl}$, range $=0.7-4.28 \mathrm{mg} / \mathrm{dl}$ ). The average time on dialysis was $74.25 \pm 32.50$ months. Three patients presented with clinical symptoms at diagnosis. These symptoms were fever and weight loss. In all patients, tumors were detected during post-transplant follow-up examinations as incidental findings on ultrasound (10 cases) and computed tomographic scan (one case).

Histologically, all malignant neoplasias of kidneys were RCC. Histological subtypes comprised conventional clear cell $(n=6,54.5 \%)$ and papillary $(n=5,45.5 \%)$ tumors. Of the papillary subtype, three were with chromophilic cytoplasm (=type 1) and two with eosinophilic cytoplasm (=type 2). There were two grade $1(18.2 \%)$, seven grade $2(63.6 \%)$ and two grade 3 (18.2\%) RCCs. Seven tumors were classified as pT2 $(63.7 \%)$, two as pT3a $(18.1 \%)$, one as pT3b $(9.1 \%)$ and one as pT4 (9.1\%). Histologically, positive lymph node status was detected in two patients with renal tumors with carcinoma infiltration of a peri-renal lymph node. 
Table I. Summary of the general findings of the study.

\begin{tabular}{|c|c|c|c|c|c|c|c|c|c|c|}
\hline \multirow[b]{2}{*}{ Gender } & \multicolumn{2}{|c|}{ Age, years } & \multicolumn{2}{|c|}{ Time, months } & \multirow[b]{2}{*}{ IS } & \multirow[b]{2}{*}{ Donor } & \multirow[b]{2}{*}{$\begin{array}{c}\text { Cause of } \\
\text { ESRD }\end{array}$} & \multirow[b]{2}{*}{ TNM } & \multirow[b]{2}{*}{ Histology } & \multirow[b]{2}{*}{$\begin{array}{c}\text { Fuhrman } \\
\text { grade }\end{array}$} \\
\hline & At KTx & $\begin{array}{c}\text { At RCC } \\
\text { diagnosis }\end{array}$ & $\begin{array}{c}\text { KTx to RCC } \\
\text { diagnosis }\end{array}$ & $\begin{array}{l}\text { Diagnosis } \\
\text { to endpoint }\end{array}$ & & & & & & \\
\hline M & 55 & 63 & 97 & 49 & TAC,MMF, steroids & $\mathrm{D}$ & Renal Dysplasia & pT3 & $\mathrm{CC}$ & II \\
\hline $\mathrm{F}$ & 62 & 64 & 31 & 58 & AZA, steroids, CYA & $\mathrm{D}$ & Obstructive & pT3 & $\mathrm{P}$ & II \\
\hline $\mathrm{F}$ & 35 & 58 & 278 & 52 & AZA, steroids, CYA & $\mathrm{L}$ & GTN & pT2 & $\mathrm{CC}$ & III \\
\hline M & 40 & 42 & 20 & 102 & AZA, steroids, CYA & $\mathrm{D}$ & GTN & pT2 & $\mathrm{CC}$ & II \\
\hline M & 52 & 56 & 55 & 10 & MMF, steroids & $\mathrm{D}$ & PCKD & pT2 & $\mathrm{P}$ & III \\
\hline $\mathrm{F}$ & 35 & 58 & 277 & 51 & AZA, steroids, CYA & $\mathrm{L}$ & GTN & pT2 & $\mathrm{P}$ & III \\
\hline M & 41 & 61 & 239 & 109 & AZA, steroids, CYA & $\mathrm{D}$ & GTN & pT4 & $\mathrm{CC}$ & I \\
\hline $\mathrm{F}$ & 60 & 75 & 170 & 21 & Sirolimus, TAC & $\mathrm{D}$ & Unknown & pT2 & $\mathrm{CC}$ & I \\
\hline M & 57 & 70 & 152 & 14 & MMF, TAC, steroids & $\mathrm{D}$ & PCKD & pT3 & $\mathrm{P}$ & II \\
\hline $\mathrm{F}$ & 18 & 33 & 180 & 26 & Sirolimus, TAC & $\mathrm{L}$ & GTN & pT2 & $\mathrm{P}$ & II \\
\hline M & 38 & 52 & 168 & 64 & TAC, MMF, steroids & $\mathrm{L}$ & $\mathrm{DM}$ & pT2 & $\mathrm{CC}$ & II \\
\hline
\end{tabular}

KTx: Renal transplantation, M: male, F: female, TAC: tacrolimus, MMF: mycophenolate mofetil, CYA: cyclosporine, AZA: azathioprine, PCKD: polycystic Kidney Disease, GTN: glomerulonephritis, DM: diabetes mellitus, ESRD: end-stage renal disease, CC: clear cell, P: papillary, D: deceased, L: living, IS: immunosuppression, RCC: renal cell carcinoma.

Table II. Analysis of the most common malignancies in our population.

\begin{tabular}{lcccccc}
\hline Cancer type & $\begin{array}{c}\text { Incidence, } \% \\
\text { (number) }\end{array}$ & $\begin{array}{c}\text { Disease-related } \\
\text { mortality (\%) }\end{array}$ & $\begin{array}{c}\text { Time from KTx to } \\
\text { diagnosis (months)* }\end{array}$ & $\begin{array}{c}\text { Time from diagnosis to } \\
\text { endpoint (months) }\end{array}$ & $\begin{array}{c}\text { TAC regimen, } \\
\text { n (\%) }\end{array}$ & $\begin{array}{c}\text { CYA regimen, } \\
\text { n (\%) }\end{array}$ \\
\hline Gastric AC & $0.32(7)$ & 85.7 & $101.86 \pm 49.06$ & $9.28 \pm 10.24$ & $3 / 7(42.9 \%)$ & $4 / 7(57.1 \%)$ \\
Lung & $0.78(17)$ & 82.4 & $91.08 \pm 59.4$ & $10.3 \pm 8.6$ & $6 / 17(35.3 \%)$ & $11 / 17(64.7 \%)$ \\
Colorectal AC & $0.41(9)$ & 88.9 & $97.14 \pm 53.23$ & $20.5 \pm 11.04$ & $7 / 9(77.8 \%)$ & $2 / 9(22.2 \%)$ \\
Breast & $0.41(9)$ & $22.2 \%$ & $71.38 \pm 55.50$ & $71 \pm 30.42$ & $5 / 9(55.6 \%)$ & $4 / 9(44.4 \%)$ \\
Prostate AC & $0.28(6)$ & $50 \%$ & $98.5 \pm 74.78$ & $45.67 \pm 11.67$ & $5 / 6(83.3 \%)$ & $1 / 6(16.7 \%)$ \\
RCC & $0.5(11)$ & $36.4 \%$ & $151.45 \pm 92.15$ & $50.54 \pm 32.80$ & $5 / 11(45.5 \%)$ & $5 / 11(45.5 \%)$ \\
\hline
\end{tabular}

KTx: Renal transplantation, AC: adenocarcinoma, RCC: renal cell carcinoma, TAC: tacrolimus, CYA: cyclosporine. *Mean \pm standard deviation.

Native kidney cancer was removed by 11 open radical nephrectomies, including two with extended lymph node dissection without major perioperative complications. The mean tumor size in the surgical specimens was $38 \pm 36 \mathrm{~mm}$ (median=28 $\mathrm{mm}$, range $=3-120 \mathrm{~mm}$ ). Modification of immunosuppressive regimen due to tumor was carried out for only one patient after diagnosis of systemic metastases by changing to rapamycin and steroid.

Table I summarizes the patient data of this study.

Analysis among malignancies. We also analyzed and compared the data of the subgroup of patients with RCC with those of the patients suffering from the most frequent de novo visceral malignancies in our total population of renal transplant recipients (8). We included patients with prostate adenocarcinoma, breast cancer, lung cancer, gastric adenocarcinoma and colorectal cancer.
We compared the incidence, the time from KTx to diagnosis of malignancy, the time of diagnosis of malignancy to the end-point, the immunosuppression and the disease-related mortality of each malignancy group with the group of patients with RCC. According to this analysis, patients with RCC seem to be diagnosed later than those with other types of malignancy $(p=0.0001)$ as well as demonstrating better outcomes in terms of diseaserelated mortality and survival during the follow-up period compared with all the other malignancies $(p=0.0001)$, with the exception of the patients with breast cancer, whose results were better $(p=0.0001)$. No correlation was found between the RCC group and any of the other groups of malignancy as far as immunosuppression and incidence are concerned.

Table II summarizes the data of the groups of the most frequent visceral malignancies in our population. 


\section{Discussion}

It is well-established that the estimated rate of RCC development in native kidney is 10 - to 100-times the incidence in the general, immunocompetent population $(0.04 \%)(25,26)$, while RCC occurrence in the graft has been reported to be less frequent, accounting for approximately $10 \%$ of cases $(5,27)$. Our series demonstrates one of the lowest incidences of RCC in native kidneys (0.5\%) (11-16, 28-34). Moreover, our results confirm those of a recent study and current literature findings, where the vast majority of renal malignancies were detected in the native kidneys of the recipients (85\%) (33). The incidence of RCC in native kidneys mostly varies from $0.35 \%$ (35) to $1.5 \%$ (11), whereas the incidence of RCC in renal allograft is generally far less frequent $(0.25 \%)(11-16,28-34,36)$. Studies with similar design to ours demonstrated an incidence of $1.3 \% \mathrm{RCC}$ in the native kidney $(11-16,28-31,33,34)$. These findings of high incidence of RCC in the native kidney of renal transplant recipients are consistent with previous observations $(32,37)$, although they were of prospective design.

The median time from KTx to development of any RCC is reportedly 4.5 years $(3,5,27)$, with median times for development of RCC in the native kidney being much shorter than those in the allograft (33). In contrast to these findings, other studies have shown a longer median time of 3.9 to 7.4 years for development of RCC after KTx (38-40). The time for RCC detection also varied from as early as 1 month to as late as 12.2 years after KTx (33).

Many risk factors have been identified as contributing to RCC development in renal transplant recipients. The duration of ESRD is suspected to be a primary determinant of risk for RCC development in the native kidney (41). Some reports indicate that patients with ESRD have approximately 100-times greater risk of RCC than age-matched healthy controls (42). Cigarette smoking, hypertension, obesity and family history are also well-established risk factors for RCC. Male gender and African American race were also independently associated with RCC (31).

Patients with ESRD are more prone to developing RCC, either by congenital predisposition (von Hippel-Lindau syndrome), or acquired cystic kidney disease, with an overall incidence of RCC in the native kidney of hemodialysis patients reported to be approximately $2 \%(43,44)$. Acquired cystic kidney disease has been identified as a strong risk factor for RCC development, with a standardized incidence ratio of RCC ranging from 3.6 to 24.1 (45). Therefore, improvements in allograft and recipient outcomes, with longer survival after reaching ESRD, are likely to be associated with further increases in the occurrence of RCC (46). RCC occurring in ESRD is characterized by a younger age at diagnosis and higher incidence rate of males to females compared with the general population (47).
Multifocality in up to $40 \%$ and bilateral occurrence in up to $20 \%$ are other clinical characteristics, which distinguishes $\mathrm{RCC}$ in renal transplant recipients from sporadic tumors in non-transplanted patients (13). Clear cell RCC is the most common subtype, although papillary RCC more frequently occurs than in non-transplanted patients.

The survival rate of patients diagnosed with malignancy after transplant, including RCC, also appears to be lower than that of the general population (36). Of interest, native kidney RCCs arising in patients with ESRD are of lower stage and lower grade compared to RCCs diagnosed in the general population, and these tumors exhibit favorable clinical and outcome features $(29,40)$. Incidental RCC can be diagnosed early in the natural history and at a curable stage through implementation of a surveillance program. In general, RCC in native kidneys is thought to be more fatal $(39,40)$. In a recent series, it was found that no cancerspecific deaths occurred from allograft tumors; however, $23.3 \%$ of cancer-specific deaths occurred in patients with cancer in the native kidney (33), with 5- and 10-year cancer-specific survival rates of $71.2 \%$ and $58.5 \%$ respectively (33).

Because of its low incidence, most transplant units worldwide do not apply any specific approach to early detection of RCC in native kidneys or renal allografts of renal transplant recipients. Moreover, no trials assessing the role of screening for RCC in this population have been conducted as far as we are aware, and previous attempts to model the performance of screening by ultrasound were shown not to be cost effective (48). Compared to a previous study that used the Australia and New Zealand Dialysis and Transplant Registry in 2008, which demonstrated a cumulative incidence of 46 per 100,000 per year, the updated extension until 2012 showed a $17.8 \%$ increase in kidneyrelated tumors (33). Although this is a small change in the incidence of RCCs after KTx, this increase, along with the poor survival rates, suggests a possible benefit in the use of screening in this population.

The current recommendations of the European Association of Urologists for screening of RCC in renal transplant recipients suggest annual screening of the allografts and native kidneys to detect renal tumors (49). However, the American Society of Transplantation and the Kidney Disease Improving Global Outcomes Clinical Practice Guidelines for the Care of the Kidney Transplant Recipient do not recommend routine screening for renal cancer after KTx (50). Although routine annual ultrasonographic screening for RCC may improve survival by up to $25 \%$, it has not been shown to be cost effective for renal transplant recipients, even for those at high risk of disease (48). Some of the underlying limitations in the use of ultrasonography as a screening tool are user dependence, lower sensitivity and specificity in detecting small tumors $(<3$ $\mathrm{cm}$ ), and uncertain performance in the presence of cystic 
Table III. Summary of current literature on renal cell carcinoma (RCC) in native kidneys and renal allografts in renal transplant recipients. All studies were retrospective except that of Neuzillet et al. (32).

\begin{tabular}{|c|c|c|c|c|c|c|c|c|}
\hline \multirow[b]{2}{*}{ Author } & \multirow[b]{2}{*}{ Year } & \multirow[b]{2}{*}{$\begin{array}{c}\text { Number of } \\
\text { patients }\end{array}$} & \multicolumn{2}{|c|}{ Incidence of RCC } & \multirow[b]{2}{*}{$\begin{array}{l}\text { Follow-up } \\
\text { (months)* }\end{array}$} & \multicolumn{2}{|c|}{ 5-Year survival } & \multirow[b]{2}{*}{$\begin{array}{c}\text { Disease-related } \\
\text { mortality }(\%)\end{array}$} \\
\hline & & & $\begin{array}{c}\text { Native } \\
\text { kidney (\%) }\end{array}$ & $\begin{array}{c}\text { Renal } \\
\text { allograft }(\%)\end{array}$ & & $\begin{array}{l}\text { Native kidney } \\
\text { RCC (\%) }\end{array}$ & $\begin{array}{c}\text { Renal allograft } \\
\text { RCC (\%) }\end{array}$ & \\
\hline Tsaur et al. (11) & 2011 & 2001 in 30 years & 1.24 & 0.26 & $58.6 \pm 62.3$ & 75.1 & 83.5 & 15.4 \\
\hline Sun et al. (35) & 2013 & 1457 in 20 years & 0.35 & N/A & $34.8 * *$ & 80 & N/A & 20 \\
\hline Goh and Vathsala (30) & 2011 & 1036 in 22 years & 0.97 & N/A & $69.6 * *$ & 100 & N/A & 0 \\
\hline Gigante et al. (53) & 2012 & 215 in 25 years & N/A & N/A & N/A & 97 & N/A & 3 \\
\hline Kato et al. (54) & 2016 & 750 in 42 years & 1.33 & 0.26 & $15.1 \pm 8.2$ & N/A & N/A & N/A \\
\hline Barama et al. (28) & 2005 & 1073 in 33 years & N/A & 0.46 & N/A & N/A & 80 & 0 \\
\hline Breda et al. (29) & 2015 & 2690 & 1.26 & N/A & $90.2 \pm 5.7$ & $>85$ & N/A & N/A \\
\hline Moon et al. (16) & 2015 & 1386 in 12 years & 1.22 & 0.14 & $31.08 * *$ & N/A & N/A & 15.8 \\
\hline Filocamo et al. (14) & 2009 & 694 in 16 years & 1.6 & N/A & 41 & 70 & N/A & 0 \\
\hline Leveridge et al. (15) & 2011 & 3568 in 42 years & 1.1 & 0.2 & $\begin{array}{c}\text { Native: } 79.2 \\
\text { Allograft: } 43.2\end{array}$ & 82 & 87.5 & $\begin{array}{c}\text { Native: } 18 \\
\text { Allograft: } 12.5\end{array}$ \\
\hline Tillou et al. (34) & 2009 & 800 in 18 years & 2.75 & N/A & 34.8 & 93.3 & N/A & 3.6 \\
\hline Karczewski et al. (12) & 2012 & 836 in 18 years & 1.3 & 0.2 & $120 \pm 38.4$ & N/A & N/A & 9.1 \\
\hline Ranasinghe et al. (33) & 2016 & 8850 in 12 years & 0.53 & 0.09 & 110.4 & 71.2 & 88.75 & 23.3 \\
\hline Neuzillet et al. (32) & 2005 & 933 in 16 years & 1.29 & N/A & $39 \pm 41$ & 82 & N/A & 18 \\
\hline Current study & 2016 & 2173 in 32 years & 0.50 & N/A & $50.54 \pm 32.80$ & 63.6 & N/A & 36.4 \\
\hline
\end{tabular}

N/A: Not available. *Data are mean values $\pm \mathrm{SD}$, except for $* *$ which are median values.

kidney disease and small scarred kidneys, which are commonly present in patients with ESRD (48). Contrast-enhanced computer tomographic scans have risks of contrast-induced nephropathy and acute kidney injury $(48,51,52)$.

The majority of RCCs in native kidney and renal allografts have been treated by organ removal (radical nephrectomy) and discontinuation of immunosuppressive therapy $(5,27,32)$. Good results can be obtained this way because radical nephrectomy achieves local control of the disease, while discontinuation of immunosuppression allows the immune system to recover and reject residual tumor cells. However, poor outcomes also have been reported in patients dying of hepatic metastases or febrile paraneoplastic syndrome soon after transplant removal.

Table III summarizes the data of current literature on the incidence of RCC in native kidneys and renal allografts in renal transplant recipients.

We are aware of the limitations of our study due to its retrospective nature. Long-term prospective studies and large registries should provide a better understanding of the different natural behavior of RCC in native kidneys.

\section{Conclusion}

In conclusion, most RCCs in renal transplant recipients are low-stage, low-grade tumors with a favorable prognosis; however, the prognosis of metastatic RCC is poor. These tumors are generally small and asymptotic and their diagnosis is usually incidental. It also seems that RCC development in the native kidney of renal transplant recipients is an early event, frequently observed within 4 to 5 years after transplantation, but it is usually diagnosed later than other malignancies in renal transplant recipients.

We believe that kidneys of renal transplant recipients should be routinely screened by ultrasound during the first 5 years after transplantation for early-stage diagnosis. This cost-effective and minimally-invasive method still provides the best predictive value in screening and diagnosing of RCC and could substantially improve patient outcomes. We advocate annual surveillance ultrasound for RCC in the pretransplant population awaiting transplant.

The mechanisms of development of RCC in native kidneys and renal allografts are not completely understood. Moreover, the different natural history of these tumors is still undefined. Further research is needed to determine whether these differences are due to particular molecular pathways or to biases in relation to the mode of diagnosis.

\section{Conflicts of Interest}

None.

\section{Funding}

None. 


\section{References}

1 Morris PJ: Transplantation - a medical miracle of the 20th century. N Eng1 J Med 351(26): 2678-2680, 2004.

2 Moris D, Lu L and Qian S: Mechanisms of liver-induced tolerance. Curr Opin Organ Transplant, 2016.

3 Penn I: Malignancy in renal transplant recipients. Saudi J Kidney Dis Transpl 7(1): 1-5, 1996.

4 Winter P, Schoeneich G, Miersch WD and Klehr HU: Tumour induction as a consequence of immunosuppression after renal transplantation. Int Urol Nephrol 29(6): 701-709, 1997.

5 Penn I: Posttransplant malignancies. Transplant Proc 31(1-2): 1260-1262, 1999.

6 Zavos G, Moris D, Vernadakis S, Bokos J, Lionaki S, Mamarelis $\mathrm{G}$, Panagiotellis $\mathrm{K}$, Zavvos V and Boletis I: Incidence and management of Kaposi sarcoma in renal transplant recipients: The Greek experience. Transplant Proc 46(9): 3199-3202, 2014.

7 Winkelhorst JT, Brokelman WJ, Tiggeler RG and Wobbes T: Incidence and clinical course of de-novo malignancies in renal allograft recipients. Eur J Surg Oncol 27(4): 409-413, 2001.

8 Zavos G, Moris D, Kostakis ID, Vernadakis S, Bokos J, Zavvos $\mathrm{V}$, Lionaki S and Boletis J: De novo visceral malignancies in renal transplant recipients: A single center experience of 2054 recipients for more than 30 years. Exp Clin Transplant 13(4): 313-318, 2015.

9 Vernadakis S, Karaolanis G, Moris D, Zavvos V, Liapis G and Zavos G: Multiple bilateral oncocytomas of the native kidneys following renal transplantation: Report of a rare case and review of the literature. World J Surg Oncol 11: 119, 2013.

10 Kasiske BL, Snyder JJ, Gilbertson DT and Wang C: Cancer after kidney transplantation in the united states. Am J Transplant 4(6): 905-913, 2004.

11 Tsaur I, Obermuller N, Jonas D, Blaheta R, Juengel E, Scheuermann EH, Kachel HG, Karalis A and Probst M: De novo renal cell carcinoma of native and graft kidneys in renal transplant recipients. BJU Int 108(2): 229-234, 2011

12 Karczewski M, Rzymski P and Karczewski J: De novo renal cell carcinoma of native kidneys in renal transplant recipients: A singlecenter experience. Exp Clin Transplant 10(4): 310-313, 2012.

13 Klatte $\mathrm{T}$ and Marberger M: Renal cell carcinoma of native kidneys in renal transplant patients. Curr Opin Urol 21(5): 376379, 2011.

14 Filocamo MT, Zanazzi M, Li Marzi V, Guidoni L, Villari D, Dattolo E and Nicita G: Renal cell carcinoma of native kidney after renal transplantation: Clinical relevance of early detection. Transplant Proc 41(10): 4197-4201, 2009.

15 Leveridge M, Musquera M, Evans A, Cardella C, Pei Y, Jewett M, Robinette M and Finelli A: Renal cell carcinoma in the native and allograft kidneys of renal transplant recipients. J Urol 186(1): 219-223, 2011.

16 Moon A, Rogers A, Talbot D and Rix D: Renal cell cancer in a european regional renal transplant population: Is there a role for immediate native renal radiological surveillance before and after transplantation? Transplant Proc 47(6): 1840-1844, 2015.

17 Moris D, Diles K and Zavos G: Renal transplantation with grafts affected by tumors: Learning from a 'near miss' case. Transpl Int 29(1): 124-125, 2016.

18 Moris D, Dounousi E and Zavos G: Donor-origin cancer in renal transplant recipients from deceased donors: Worth gambling? Transpl Int 28(2): 253-254, 2015.
19 Elmore JM, Kadesky KT, Koeneman KS and Sagalowsky AI: Reassessment of the 1997 TNM classification system for renal cell carcinoma. Cancer 98(11): 2329-2334, 2003.

20 Fuhrman SA, Lasky LC and Limas C: Prognostic significance of morphologic parameters in renal cell carcinoma. Am J Surg Pathol 6(7): 655-663, 1982.

21 Lionaki S, Panagiotellis K, Moris D, Daikos G, Psyhogiou M, Vernadakis S, Zavos G and Boletis JN: Clostridium difficile infection among kidney transplant recipients: Frequency, clinical presentation, and outcome. APMIS 123(3): 234-239, 2015.

22 Kakavia K, Moris D, Karatza E, Bokos J, Vernadakis S, Barlas A, Sotirchos G, Diles K, Drakopoulos S and Zavos G: Intestinal perforation in renal transplant recipients: A single-center experience of 2123 recipients. Exp Clin Transplant, 2016.

23 Kostakis ID, Moris DN, Barlas A, Bokos I, Darema M, Theodoropoulou E, Karaolanis G, Kostakis A, Boletis I and Zavos G: Impact of donor and recipient age difference on longterm allograft survival after living donor renal transplantation: Analysis of 478 cases. Clin Transplant 27(6): 838-843, 2013.

24 Moris D, Davakis S, Kakavia K, Bokos J, Vernadakis S, Diles K, Sotirchos G, Barlas A, Psychogiou M and Zavos G: Incisional infections after renal transplant: Outcome data from 238 consecutive recipients. Exp Clin Transplant, 2016.

25 Doublet JD, Peraldi MN, Gattegno B, Thibault P and Sraer JD: Renal cell carcinoma of native kidneys: Prospective study of 129 renal transplant patients. J Urol 158(1): 42-44, 1997.

26 Cheung CY, Lam MF, Lee KC, Chan GS, Chan KW, Chau KF, Li CS, Chan TM and Lai KN: Renal cell carcinoma of native kidney in chinese renal transplant recipients: A report of 12 cases and a review of the literature. Int Urol Nephrol 43(3): 675-680, 2011.

27 Penn I: Primary kidney tumors before and after renal transplantation. Transplantation 59(4): 480-485, 1995.

28 Barama A, St-Louis G, Nicolet V, Hadjeres R and Daloze P: Renal cell carcinoma in kidney allografts: A case series from a single center. Am J Transplant 5(12): 3015-3018, 2005.

29 Breda A, Lucarelli G, Rodriguez-Faba O, Guirado L, Facundo C, Bettocchi C, Gesualdo L, Castellano G, Grandaliano G, Battaglia M, Palou J, Ditonno P and Villavicencio H: Clinical and pathological outcomes of renal cell carcinoma (RCC) in native kidneys of patients with end-stage renal disease: A longterm comparative retrospective study with rcc diagnosed in the general population. World J Urol 33(1): 1-7, 2015.

30 Goh A and Vathsala A: Native renal cysts and dialysis duration are risk factors for renal cell carcinoma in renal transplant recipients. Am J Transplant 11(1): 86-92, 2011.

31 Klein J, Gonzalez SA, Fischbach BV, Yango AF, Rajagopal A, Rice KM, Saim M, Barri YM, Melton LB, Klintmalm GB and Chandrakantan A: Routine ultrasonography surveillance of native kidneys for renal cell carcinoma in kidney transplant candidates. Clin Transplant 30(8): 946-953, 2016.

32 Neuzillet Y, Lay F, Luccioni A, Daniel L, Berland Y, Coulange C and Lechevallier E: De novo renal cell carcinoma of native kidney in renal transplant recipients. Cancer 103(2): 251-257, 2005.

33 Ranasinghe WK, Suh N and Hughes PD: Survival outcomes in renal transplant recipients with renal cell carcinoma or transitional cell carcinoma from the anzdata database. Exp Clin Transplant 14(2): 166-171, 2016.

34 Tillou X, Demailly M, Hakami F, Westeel PF, Saint F and Petit $\mathrm{J}$ : De novo renal carcinoma in renal transplant recipients: Effect of early treatment. Transplant Proc 41(8): 3314-3316, 2009. 
35 Sun IO, Ko YM, Kim EY, Park KS, Jung HS, Ko SH, Chung BH, Choi BS, Park CW, Kim YS and Yang CW: Clinical characteristics and outcomes in renal transplant recipients with renal cell carcinoma in the native kidney. Korean J Intern Med 28(3): 347-351, 2013.

36 Miao Y, Everly JJ, Gross TG, Tevar AD, First MR, Alloway RR and Woodle ES: De novo cancers arising in organ transplant recipients are associated with adverse outcomes compared with the general population. Transplantation 87(9): 1347-1359, 2009.

37 Ianhez LE, Lucon M, Nahas WC, Sabbaga E, Saldanha LB, Lucon AM and Srougi M: Renal cell carcinoma in renal transplant patients. Urology 69(3): 462-464, 2007.

38 Hevia V, Gomez V, Diez Nicolas V, Alvarez S, Gomez Del Canizo C, Galeano C, Gomis A, Garcia-Sagredo JM, Marcen R and Burgos FJ: Development of urologic de novo malignancies after renal transplantation. Transplant Proc 46(1): 170-175, 2014.

39 Melchior S, Franzaring L, Shardan A, Schwenke C, Plumpe A, Schnell R and Dreikorn K: Urological de novo malignancy after kidney transplantation: A case for the urologist. J Urol 185(2): 428-432, 2011.

40 Neuzillet Y, Tillou X, Mathieu R, Long JA, Gigante M, Paparel $\mathrm{P}$, Poissonnier L, Baumert H, Escudier B, Lang H, RiouxLeclercq N, Bigot P, Bernhard JC, Albiges L, Bastien L, Petit J, Saint F, Bruyere F, Boutin JM, Brichart N, Karam G, Branchereau J, Ferriere JM, Wallerand H, Barbet S, Elkentaoui H, Hubert J, Feuillu B, Theveniaud PE, Villers A, Zini L, Descazeaux A, Roupret M, Barrou B, Fehri K, Lebret T, Tostain J, Terrier JE, Terrier N, Martin L, Dugardin F, Galliot I, Staerman F, Azemar MD, Irani J, Tisserand B, Timsit MO, Sallusto F, Rischmann P, Guy L, Valeri A, Deruelle C, Azzouzi AR, Chautard D, Mejean A, Salomon L, Rigaud J, Pfister C, Soulie M, Kleinclauss F, Badet L, Patard JJ, Comite de Transplantation de l'Association Francaise dU and Comite de Cancerologie de l'Association Francaise dU: Renal cell carcinoma (RCC) in patients with end-stage renal disease exhibits many favourable clinical, pathologic, and outcome features compared with rec in the general population. Eur Urol 60(2): 366-373, 2011.

41 Stewart JH, Buccianti G, Agodoa L, Gellert R, McCredie MR, Lowenfels AB, Disney AP, Wolfe RA, Boyle P and Maisonneuve $P$ : Cancers of the kidney and urinary tract in patients on dialysis for end-stage renal disease: Analysis of data from the United States, Europe, and Australia and New Zealand. J Am Soc Nephrol 14(1): 197-207, 2003.

42 Nouh MA, Kuroda N, Yamashita M, Hayashida Y, Yano T, Minakuchi J, Taniguchi S, Nomura I, Inui M, Sugimoto M and Kakehi Y: Renal cell carcinoma in patients with end-stage renal disease: Relationship between histological type and duration of dialysis. BJU Int 105(5): 620-627, 2010.

43 Schwarz A, Vatandaslar S, Merkel S and Haller H: Renal cell carcinoma in transplant recipients with acquired cystic kidney disease. Clin J Am Soc Nephrol 2(4): 750-756, 2007.
44 Chow WH, Dong LM and Devesa SS: Epidemiology and risk factors for kidney cancer. Nat Rev Urol 7(5): 245-257, 2010.

45 Holley JL: Screening, diagnosis, and treatment of cancer in longterm dialysis patients. Clin J Am Soc Nephrol 2(3): 604-610, 2007.

46 Vajdic CM, McDonald SP, McCredie MR, van Leeuwen MT, Stewart JH, Law M, Chapman JR, Webster AC, Kaldor JM and Grulich AE: Cancer incidence before and after kidney transplantation. JAMA 296(23): 2823-2831, 2006.

47 Denton MD, Magee CC, Ovuworie C, Mauiyyedi S, Pascual M, Colvin RB, Cosimi AB and Tolkoff-Rubin N: Prevalence of renal cell carcinoma in patients with esrd pre-transplantation: A pathologic analysis. Kidney Int 61(6): 2201-2209, 2002.

48 Wong G, Howard K, Webster AC, Chapman JR and Craig JC: Screening for renal cancer in recipients of kidney transplants. Nephrol Dial Transplant 26(5): 1729-1739, 2011.

49 Dunnick NR: Renal cell carcinoma: Staging and surveillance. Abdom Radiol (NY) 41(6): 1079-1085, 2016.

50 Kidney Disease: Improving Global Outcomes Transplant Work G: Kdigo clinical practice guideline for the care of kidney transplant recipients. Am J Transplant 9(Suppl 3): S1-155, 2009.

51 Argyrou C, Moris D and Vernadakis S: Steering between scylla and charybdis: Picking out the optimum time of double-j stent removal following renal transplantation. Transplant Rev (Orlando), 2016.

52 Mamarelis G, Vernadakis S, Moris D, Altanis N, Perdikouli M, Stravodimos K, Pappas P and Zavos G: Lithiasis of the renal allograft, a rare urological complication following renal transplantation: A single-center experience of 2,045 renal transplantations. Transplant Proc 46(9): 3203-3205, 2014.

53 Gigante M, Neuzillet Y, Patard JJ, Tillou X, Thuret R, Branchereau J, Timsit MO, Terrier N, Boutin JM, Sallusto F, Karam G, Barrou B, Chevallier D, Mazzola CR, Delaporte V, Doeffler A, Kleinclauss F, Badet L, members of the Comite de Cancerologie de l'Association Francaise dU and Comite de Transplantation de l'Association Francaise dU: Renal cell carcinoma ( $\mathrm{rcc}$ ) arising in native kidneys of dialyzed and transplant patients: Are they different entities? BJU Int 110(11 Pt B): E570-573, 2012.

54 Kato T, Kakuta Y, Abe T, Yamanaka K, Imamura R, Okumi M, Ichimaru N, Takahara $\mathrm{S}$ and Nonomura $\mathrm{N}$ : The benefits of cancer screening in kidney transplant recipients: A single-center experience. Cancer Med 5(2): 153-158, 2016.

Received November 24, 2016

Revised December 21, 2016

Accepted December 22, 2016 